\title{
Flyash as a Sustainable Alternate Building Material for Low Cost Housing
}

\author{
Shruti Mutkekar ${ }^{1}$, Shweta Patil ${ }^{2}$ \\ ${ }^{1}$ Department of Architecture, Gogte Institute of Technology, Visvesvaraya Technological University, Udyambag, Belgaum, India, \\ 590008 \\ ${ }^{2}$ Department of Civil Engineering, Gogte Institute of Technology, Visvesvaraya Technological University, Udyambag, Belgaum, India, \\ 590008
}

\begin{abstract}
Housing is major problem faced by developing countries like India. The most basic building material for construction of permanent houses is the burnt clay brick, Cement and steel. A significant quantity of raw material and fuel is utilized in making these conventional building materials and even the manufacturing processes of these materials create environmental problems. This paper presents study on sustainable and low-cost alternative building material - Flyash, having advantages on areas where conventional building material for housing is expensive and hazardous to environment.
\end{abstract}

Keywords: Low cost housing, Fly ash, Sustainable, Building material

\section{Background / Introduction}

Population explosion in India has created several problems one of them is housing. Managing the response to the continuous increasing housing needs of Indian population, has long been a problem for its government. Providing affordable housing remains a major concern of the government. Housing shortages have stimulated efforts to develop alternate building materials and construction methods that use minimal resources because of the increasing shortage of energy and raw materials.

To achieve the current housing requirement the scale of economic investment is huge and this will even lead to shortage of conventional building material for construction. This shortage of conventional building material is aggravating the situation of affordable houses. [1]

It also needs to be recognized that the construction industry adversely affects the environment, through physical disruption, the depletion of key renewable resources like fertile topsoil, forest cover and excessive consumption of energy. Therefore, there is a strong need to adopt environmentally appropriate materials by up-gradation of the conventional materials [2].

Due to limited national resources -both financial and conventional building materials, there is a need to use alternative building materials, which are sustainable and cost effective to meet the Housing demand.

Flyash can be used as an alternative material for burnt clay bricks, which is one of the important building materials, used for construction of housing and buildings. The Flyash used in concrete, can substitute the conventional building material like Cement and clay bricks in nearly all applications [3].

\section{Low Cost Housing}

Low cost housing may be defined as a provision of housing, which caters to the requirements of masses within their income capabilities, without sacrificing the strength, performance and life of the structure. Low cost housing is to reduce construction cost through appropriate use of materials, skills and technology but without sacrificing the performance and structure life. Low cost housing technologies and to cut down construction cost [4].

\section{Low Cost Housing Materials}

In a house, materials form a major component - 65 to $75 \%$ of the total construction. It is widely accepted that the cost of building a house must be brought down to an affordable level by using innovative cost effective building materials.

In India the Construction materials can be divided in to three categories:

1) Traditional material: mud, thatch, bamboo, timber, bricks, stone, clay roofing tiles etc.

2) Conventional Materials: Cement, steel, glass, plastic etc.

3) Innovative materials: agricultural waste, stabilized soil and cement blocks, Industrial waste such as Flyash for cement and bricks.

In the selection of building materials the following factors play important role:

1) Availability

2) Cost effectiveness (life cycle cost)

3) Durability (strength of material)

4) Maintainability

The traditional materials are still widely used in rural areas. The main reason for such wide use is the availability of these materials locally at low cost. The initial construction cost of these traditionally build houses is lower but the life span and durability of house is also less when compared with houses built with conventional materials [1]. 


\section{International Journal of Science and Research (IJSR) \\ ISSN (Online): 2319-7064}

Index Copernicus Value (2015): 78.96 | Impact Factor (2015): 6.391

Due to increase in demand and shortage of material, there is increase in the cost of the Conventional materials like Cement, Sand etc. So to build houses economically by utilizing industrial waste like Fly ash, can act as excellent alternate building material. But the adoption of any alternative material on large scale needs proper research and study. The product cannot be accepted by the industry unless it is effective and economical.

\section{Environmental Concern}

Climate change is considered as major environmental challenge for the world. Buildings have a significant and continuously increasing impact on the environment since they are responsible for a large portion of carbon emissions and also uses considerable number of resources. Buildings account for one-sixth of the world's fresh water withdrawals, one quarter of its wood harvest, and two-fifths of its material and energy flows. The construction sector consumes considerable amount of energy from the production of basic building materials, its transportation and assembling called embodied energy [2].

Brick and cement are one of the profuse pollutant industries with massive $\mathrm{CO}_{2}$ emissions. It is estimated that each million clay bricks cause to generate 300 tons of $\mathrm{CO}_{2}$ and each million tons of OPC cause to generate equal quantity of $\mathrm{CO}_{2}[5]$.

\section{Flyash as a Sustainable Alternative Building Material}

Due to growing environmental concerns and the need for cleaner production, the management of Fly ash has become an important issue facing the power generation industry. For that reason, many researchers are actively working to find new and improved methods of reducing the Fly ash waste disposal problem, particularly by establishing its useful and economic utilization.

The utilization of Fly ash in concrete as partial replacement of cement is gaining immense importance today, mainly on the account of improvement in durability of concrete with its ecological benefits. Another considerable interest in many parts of the world is the utilization of Flyash in brick manufacturing [6].

Even though research and development and suprimental construction has shown that Fly ash can be used with considerable advantages in building construction, the construction industry has still not taken to the use of Fly ash to any large extent.

The reasons assigned for this may be:

1) Unawareness of the usefulness of Fly ash in conjunction with lime, cement or bricks in the various constructions.

2) Unavailability of ready mix lime Fly ash mixture of standard quality [3].

\subsection{What is Fly ash?}

Pulverized fuel ash commonly known as Fly ash, is comprised of the non-combustible mineral portion of coal. When coal is consumed in a power plant, it is first ground to the fineness of powder. Blown into the power plant's boiler, the carbon is consumed - leaving molten particles rich in silica, alumina and calcium. These particles solidify as microscopic, glassy spheres that are collected from the power plant's exhaust before they can "fly" away - hence the product's name: Fly ash. Fly ash is a pozzolanic when mixed with lime (calcium hydroxide), pozzolanic combine to form cementitious compounds. Concrete containing Fly ash becomes stronger, more durable, and more resistant to chemical attack [6].

There are about 40 major thermal power plants in India, which produces about 15 million tones of Fly ash every year. Such enormous quantities need huge dumping grounds and create pollution problems.

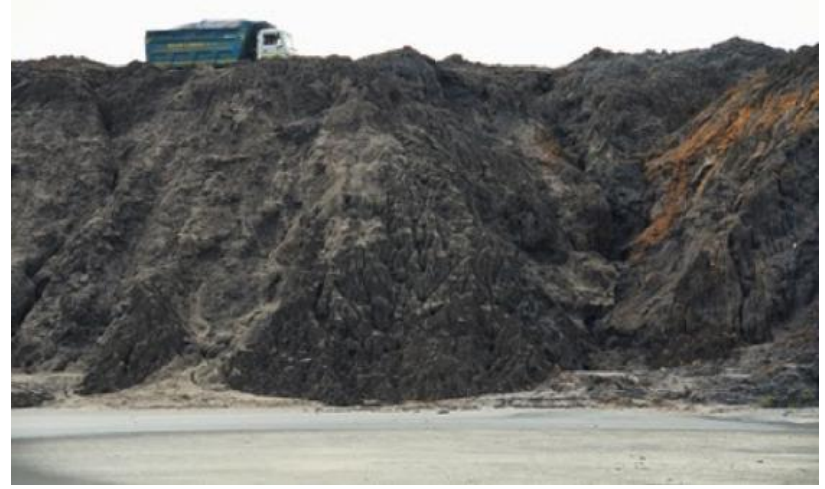

\subsection{Classification of Fly ash}

ASTM C618 classifies the Fly ash into two classes:

a) Class $\mathrm{F}$

b) Class $\mathrm{C}$

\section{Class F Fly ash:}

Fly ash normally produced from burning anthracite or bituminous coal falls in this category. This class of Fly ash exhibits pozzolanic property but rarely if any, self-hardening property. In Class F Fly ash, total calcium typically ranges from 1 to 12 percent, mostly in the form of calcium hydroxide, calcium sulphate, and glassy components in combination with silica and alumina.

\section{Class C Fly ash:}

Fly ash normally produced from lignite or sub- bituminous coal is the only material included in this category. This class of Fly ash has both pozzolanic and varying degree of selfcementitious properties. Most class C Fly ashes contain more than $15 \% \mathrm{CaO}$. But some class $\mathrm{C}$ Fly ashes may contain as little as $10 \% \mathrm{CaO}$ [7].

\subsection{Potential areas for Fly ash utilization: [8]}

Fly ash in Geopolymer

Geopolymer concrete with Flash produced a concrete with 


\section{International Journal of Science and Research (IJSR) \\ ISSN (Online): 2319-7064}

Index Copernicus Value (2015): 78.96 | Impact Factor (2015): 6.391

high compressive strength, low creep, good acid resistance and low shrinkage. The role of binder in concrete is replaced by Fly ash based geopolymer paste, which also possesses pozzolanic properties as OPC and high alumina and silicate content.

\section{Fly ash bricks}

Fly ash bricks have a number of advantages over the conventional clay bricks and concrete brick in term of its properties. Fly ash can also produce unglazed tiles for use on footpaths.

\section{Fly ash in manufacture of cement}

Fly ash is suitable for use as pozzolanic materials. In the presence of moisture, it reacts chemically with calcium hydroxide at room temperature to form compounds possessing cementitious properties. Fly ash has a high amount of silica and alumina in reactive form which complements the hydration chemistry of cement. This property makes Fly ash an excellent admixture for producing concrete.

\section{Fly ash in ceramics}

A process to produce ceramics from Fly ash having superior resistance to abrasion had been developed.

\section{Fly ash in road construction}

Fly ash can be used to stabilize the soil for sub based in road construction

\subsection{Fly ash in concrete}

Fly ash (FA) is a powdery pozzolona capable of utilizing both heat and calcium hydroxide generated during cement hydration of Portland cement(PC). Hence, it has become partial replacement material .The utilization of Fly ash as a pozzolanic material results in considerable improvements such as lower heat of hydration, less water requirements, reduced permeability resulting in durable concrete, increased resistance to chemical attack by sulphates and chlorides and reduced risk of alkali aggregate reaction.

As Fly ash particles are finer than cement particles it improves the particle packing and reduces the amount of non surface adsorbed water, required to obtain certain workability in concrete and mortars this is likely to improve the particle packing at the aggregate surface in particular.

First of all, the spherical shape of Fly ash creates a ball bearing effect in the mix, improving workability without increasing water requirements. Fly ash also improves the pump-ability of concrete by making it more cohesive and less prone to segregation. In addition, some Fly ashes have been shown to significantly decrease heat generation as the concrete hardens and strengthens.

The biggest reason to use Fly ash in concrete is the increased life cycle expectancy and increase in durability associated with its use. During the hydration process, Fly ash chemically reacts with the calcium hydroxide forming calcium silicate hydrate and calcium aluminate, which reduces the risk of leaching calcium hydroxide and concrete's permeability. Fly ash also improves the permeability of concrete by lowering the water-to-cement ratio, which reduces the volume of capillary pores remaining in the mass. The spherical shape of Fly ash improves the consolidation of concrete, which also reduces permeability [2].

\subsubsection{Effect of Flyash on Properties of Concrete [9]}

a) Fresh concrete

- Improved workability

- Reduced water demand for most Fly ashes.

- Produced concrete with more cohesive and segregates less-improved pump ability.

- Reduced bleeding especially at high replacement level.

\section{b) Set time}

- Extended-especially in cold water.

- Can increased or retarded the setting time for certain combinations of Fly ash, cement and chemical admixtures.

\section{c) Heat of hydration}

- Reduced for Class F Fly ash at normal levels of replacement, Class C Fly ashes have to be used at higher levels of replacement to reduce heat (for example $\geq 50 \%$ ).

- Increased in reduction by using high levels of replacement, low total cementitious contents, and low concrete placing temperature.

d) Early age strength

- Reduced the early strength of concrete especially at first day.

- Class F will have a greater reduction and for higher replacement levels of Fly ash.

\section{e) Long term strength}

- Improved long term strength.

- Strength improved with the increment of replacement level of Fly ash.

f) Permeability and chloride resistance

- Reduced by time.

g) Expansion (alkali-silica reaction)

- Reduced.

- Sufficient levels of replacement can completely suppress deleterious.

\section{h) Sulfate resistance}

- Increased for class F Fly ash.

- Resistance to cyclic immersion in sodium sulphate solution and drying has been shown to be relatively unaffected by up to $40 \%$ Fly ash.

\section{i) Resistance to carbonation}

- Decreased.

- Significant decreases when high levels of Fly ash are used in poorly- cured, low-strength (high w/cm) concrete.

\subsection{Fly ash Bricks}

Bricks may be made from a number of different kinds of material, but they must usually possess (can be capable of developing) a certain amount of plasticity. Fly ash is one of them. Use of Fly ash with soil and firing the bricks with agricultural waste will reduce the cost of the building material i.e. Clay bricks. Fly ash is an industrial waste, which is just a burden for the industry we can take it free of

\section{Volume 6 Issue 7, July 2017




\section{International Journal of Science and Research (IJSR) \\ ISSN (Online): 2319-7064}

Index Copernicus Value (2015): 78.96 | Impact Factor (2015): 6.391

cost from the industries and can utilize it for the manufacturing of fly ash bricks[8].

\subsubsection{Clay-Flyash burnt bricks:}

Flyash generally contains 5 to $6 \%$ of unburnt carbon, incorporation of Flyash, therefore, results into a better-burnt product together with an economy in fuel consumption. It has been experimentally verified that saving of about five tons of coal per Lac bricks could be achieved by mixing $40 \%$ flash ash by volume with the clay for making bricks.

Advantages of Clay Flyash Bricks:

a) Reduction in drying shrinkage and about 15 to $25 \%$ of the weight of the bricks with better thermal insulation.

b) The properties of bricks are not affected by mixing Fly ash with the clay [1].

\subsubsection{Fly ash lime bricks}

Fly ash sand-lime bricks can be used as an alternative material for burnt clay bricks, which is one of the important building materials used for construction of housing and buildings.

These bricks are chemically bonded bricks manufactured by utilizing $80-82 \%$ of Fly ash, 9-10\% of lime, $9-10 \%$ of sand and $0.2 \%$ of Chemical accelerator (Covered by Central Fuel Research Institute, Dhanbad's patent). For manufacturing Fly ash lime bricks no firing is needed. Curing in steam for predetermined period is employed to enable the bricks to gain desired strength. Thus, Fly ash lime bricks satisfy the basic parameters of building units, moreover the bricks are also suitable for the construction of building in coastal areas where normal red clay burnt bricks are found to be affected.

Various special features of Fly ash lime bricks are as follows:

a) Being machine finished these are uniform in size and shape.

b) Consumes 20-25 percentless cementmortar.

c) Stronger than Class-I, burnt clay-building bricks.

d) Outside wall plastering is not essential as these bricks have cement gray colour, smooth surface and low water absorption capacity.

e) Resistance to salinity.

f) Being lighter in weight in comparison to the conventional red bricks, the dead building load and the transportation cost will be less.

g) Adoption of this process helps to conserve invaluable topsoil of agricultural land.

h) By consuming $80-82 \%$ Fly ash, the cause of environmental pollution and hazards due to disposal is minimized.

i) As firing of the bricks is not needed thus pollution due to firing is eliminated [3].

\subsubsection{Flyash-Sand-Lime-GypsumBricks:}

Fly ash, lime and gypsum are available in mutual proximity in many regions. An economical alternative to conventional burnt clay bricks will be available, if these materials can be used to make bricks and hollow blocks of adequate strength [8]. Flyash-Sand-Lime-Gypsum Bricks can be used for walls in housing and all types of building construction. These bricks are manufactured by utilizing Flyash (60\%), Sand (20\%), Lime (15\%), Gypsum (5\%)[5].

\section{Clay Bricks vs. Flyash Bricks}

One of the most promising building materials for many countries is the fired clay brick. Traditionally produced fired clay brick production plays a major role in the informal economy [6].

However, it is hampered by a number of problems:

- Brick makers have little training, the quality of brick produced is low and supply is irregular.

- Great quantities of firewood are needed for production while energy loss

- The process is damaging to the environment [11].

On the other hand, in many countries, electricity is often supplied by coal-powered generators. In the power stations, approximately $80-90 \%$ of the ash formed from burnt coal is carried out of the furnace, then extracted from the flue gas and is known as Fly ash. Large quantities of Fly ash produced as a by-product of coal-based power stations have been viewed as a serious environmental problem. It is not surprising that with growing environmental awareness, there has been considerable interest in the use of Fly ash in the brick manufacturing industries. Fly ash is less energy intensive compared to clay bricks and helps keeping clean environment [11].

\subsubsection{Environmental benefits of Fly ash:}

1) Fly ash utilization reduces the requirement of clay, sand, lime stone in cement manufacturing and hence conserves natural resources.

2) Fly ash utilization reduces the cement requirement and hence carbon-di- oxide liberation during cement manufacturing is reduced.

3) Fly ash utilization reduces the topsoil requirement for land filling / brick manufacturing and saves agricultural land.

4) Fly ash utilization achieves increased strength of the finished concrete product without increasing the cement content [3].

\section{Conclusion}

Coal is the main energy source in India and Fly ash results as a by-product of coal combustion. Dumping of Fly ash poses environmental problems. It has been proved that the basic properties of Fly ash if used consciously and precisely it can be turned out to be a successful material. Replacing Cement by Fly ash in concrete mix will minimize environmental impact. This recycling of waste material like Fly ash as replacement for cement , provides a large setting for the disposal of Fly ash in a very efficient, useful and profitable way.

In this study, Fly ash as a sustainable alternate building material is studied and the potential of this material to be used as alternate building materials is brought out. Proper awareness needs to be created in the housing sector for the use of Fly ash as an Alternate building material for the low cost housing. This material if studied and developed properly holds the key to address the current housing needs. Mass housing targets can be achieved by replacing the conventional materials and more than that, the process of 


\section{International Journal of Science and Research (IJSR) \\ ISSN (Online): 2319-7064}

Index Copernicus Value (2015): 78.96 | Impact Factor (2015): 6.391

making use of industrial waste material like Fly ash in large quantities, is more environmentally acceptable.

\section{References}

[1] Vastu Shilpa Foundation for Studies and Research in Environmental Design, 'Low Cost Housing- an analytical study of the current practices and techniques', Sangath Ahmedabad, January 1983.

[2] Shruti Mutkekar and Shweta Patil, 'Flyash as an Alternative Energy Efficient Building Material for Cement', International Journal of Current Engineering and Technology, E-ISSN 2277-4106, P- ISSN 23475161, @2015 INPRESSCO®, Available at http://inpressco.com/category/ijcet, Vol.5, No.2 (April 2015)

[3] 'Techno Economic Feasibility Report on Flyash Bricks', BMPTC-Building Materials \& Technology Promotion Council Ministry of Housing \& Urban Poverty Alleviation Government of India, New Delhi

[4] Preetpal Singh and Gurjeet Kumar, 'Low Cost Housing: Need for todays World', International Journal of Engineering Research-Online, A Peer Reviewed International Journal, ISSN: 2321-7758, Vol.4, Issue.3, 2016 (May- June).

[5] 'Environment Friendly Indian Building Material Technologies for Cost Effective Housing' - Society for Excellence in Habitat Development, Environment Protection and Employment generation [SHEE], New Delhi.

[6] Swaptik Chowdhury and Sangeeta Roy, 'Prospects of Low Cost Housing in India', published in Scientific Research, Geomaterials, 2013, 3, 60-65.

[7] Xu Lingling.Guo Wei.Wang Tao.Yang Nanru, 'Study on fired bricks with replacing clay by fly ash in high volume ratio', published in Construction and Building Materials, Volume 19, Issue 3, April 2005, Pages 243247.

[8] Vivek Kumar, Vidit Gupta, Shivam Sagar, Sushant Singh, Mohd. Haroon, 'A Review Study on Alternate Low Cost Construction Materials \& Techniques for Building Design', International Research Journal of Engineering and Technology (IRJET), e- ISSN: 2395- 0056, p- ISSN: 2395- 0072, Volume:04, Issue: 04, Apr- 2017.

[9] Michael Thomas, Ph.D., P.Eng. Professor of Civil Engineering, University of New Brunswick, 'Optimizing the Use of Flyash in Concrete', PCAPortland Cement Association, Illinois.

[10] Norshahrizan Nordin, Mohd Mustafa Al Bakri Abdullah, Muhammad Faheem Mohd Tahir, Andrei Victor Sandu, Kamarudin Hussin, 'Utilization Of Flyash Waste As Construction Material', International Journal Of Conservation Science, Issn: 2067-533x Volume 7, Issue 1, January-March 2016: 161-166.

[11] Andreas Nataatmadja, 'Development of low-cost Flyash bricks', School of Urban Development, Queensland University of Technology (email: a.nataatmadja@qut.edu.au )

\section{Author Profile}

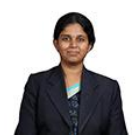

Prof. Shruti Mutkekar was born on $27^{\text {th }}$ Nov, 1981.She received her B.Arch degree from Gogte Institute of Technology, Belgaum. She is working as Associate Professor in Gogte Institute of Technology College, Belgaum.

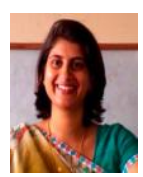

Prof Shweta Patil was born in Belgaum on April $2^{\text {nd }}$, 1978. She received her B. E. (civil) from Gogte Institute of Technology, Belgaum and M.Tech Structural from Gogte Institute of Technology, Belgaum since 2004. She is working as Assistant Professor in Gogte Institute of Technology College, Belgaum. Her research interest is study of properties of fly ash concrete at elevated temperature. She registered for $\mathrm{Phd}$ in the Guide- $\mathrm{Dr}$ K.B.Prakash, Principal of Haveri Engineering College Visvesvaraya Technological University. 